\title{
AyURLOG
}

National Journal of Research in Ayurved Science

http://www.ayurlog.com $\quad$ April- June: 2021|Volume: 09 th $^{\text {th }}$ Issue: $2^{\text {nd }}$

ISSN: 2320-7329

\section{Evaluation of the efficacy of Raktamokshana by cupping method in Vatapradhana Katigata-Vata.}

\author{
Shivanand F. Kawane ${ }^{* 1}$, Yogesh Sharma ${ }^{2}$, Shital S Kawane ${ }^{3}$,
}

1. Assistant Professor Shalya Tantra Dept., RPA Ayurved Mahavidyalaya, Purna , Maharashtra, india 431511

2. Nashik Maharashtra, India 422003, Contact no: 8770867132, Email address: yogeshsharma281680@gmail.com

3. Umarkhed, Maharashtra, India 445206; Contact no: 7420842759, Email address: bansodesw@gmail.com

*Corresponding author: Contact no: 9860934399, Email address: shivadada.strah@gmail.com

\begin{abstract}
With the advancement of age, each individual suffering backache once in his lifetime. In the clinical practice maximum number of patients visiting a doctor have symptoms of Low Back Pain (LBP). Taking into consideration, the frequency of this ailment various modalities of treatment such as NSAIDs, steroids, physiotherapy and lastly operative measures are implied on patients which have its own drawback like having temporarily relief, adverse sideeffects, costly affair etc. In case of Ayurvedic Treatment: snehana, swedana, basti Karma, Agni Karma \& Raktamokshana need to be implemented. An effort has been made to establish the practice of Raktamokshana with cupping method. Raktamokshana is done by after prachhan Karma and applying transparent vacuum cups to drain vitiated dosha along with the impure blood. It is very similar to Ghati Yantra explained in the
\end{abstract}

classics that is the Sushruta Samhita. A single arm study was conducted on 10 patients of katigatavata and were treated with Raktamokshana by cupping method. A significant relief was observed in the patients complains. So, it can be concluded that cupping method is an efficient modality for Raktamokshana for patients suffering from Katigata-Vata.

Keywords: Katigata Vata, Pain, Raktamokshana, Cupping Method, prachhan Karma

\section{INTRODUCTION}

In Ayurveda,Vata dosha dushti and sthansanshray can be seen on various sites, e.g. Sphika (gluteal region), Kati-Prishtha (thoraco-dorsal), Janu (knee), Jangha (thigh), Pada (feet). Achharya sushruta consider rakta as a fourth dosha of our body. Although the illness is not life-threatening, the pain caused 
by it severely disrupts the patient's routine. Effective treatment with painkillers, steroids, ice packs, physiotherapy are all temporarily satisfactory. For good outcomes, the patients finally turn to Ayurveda. The treatment modality for Vatavyadhis includes Snehana, Swedana, Basti Chikitsa, Agni Karma and Raktamokshana.

"Raktamokshana" is one of the methods cited by Sushrutacharya ${ }^{2}$ for the treatment of 'ekangsthit vata dosha'i.e. katigata-vata.

"एकाड्गगगं च मतिमाज्छड्ग्गेश्वावस्थितं जयेत् ॥ ११॥"“

He says, by Raktamokshana we let out vitiated Rakta Dhatu along with the doshas thereby relieving cardinal symptoms of Katigata-Vata. To expel out the vitiated blood, six procedures are mentioned: Sira Vedhan (Venesection), Shrungavacharana (horn application), Alabuavacharana (pumpkin application), Jalaukavacharana (leech application), Prachanna Karma (superficial pricks), Ghati Yantra Avacharana (clay pot application) ${ }^{2}$. In this study, patients with Katigata-Vata symptoms were treated with Raktamokshana using the Cupping Method.

AIM - Evaluation of the efficacy of Raktamokshana by method of cupping in katigatavata with special reference to Low backache.

\section{OBJECTIVES}

- To test the efficacy of Raktamokshana in katigatavata

- To discover a novel form of treatment for Low back pain seen in all groups of population.

- To validate the age-old practice of Raktamokshana

\section{STUDY DESIGN}

It is a single arm open study wherein Ten patients of katigatavata were randomly selected from the OPD and IPD and were enrolled in the research study.

\section{STUDY POPULATION}

The research was performed in 10 patients who had complains of Katigata-Vata for treatment in the Ayurvedic hospital. Raktamokshana was performed in the Kati (low back) area with the use of 26 no. needle and cupping method in three settings $\left(0,5^{\text {th }}\right.$, and $10^{\text {th }}$ day). Signs and symptoms were given scores based on their severity.

\begin{tabular}{|l|l|}
\hline Points & $\begin{array}{l}\text { Experimental } \\
\text { group }\end{array}$ \\
\hline Number of patients & 10 \\
\hline Treatment & Cupping method \\
\hline Follow up of & $0,5,10^{\text {th }}$ day \\
\hline $\begin{array}{l}\text { Mode } \\
\text { Administration }\end{array}$ \\
\hline Duration of treatment & 10 days \\
\hline Criteria for inclusion: \\
\hline Copi.notion Both gender: men and women \\
ii. Age ranges 35-75 years of age \\
iii. Patients complaining of low back \\
iv. Pain Patients with normal muscle power.
\end{tabular}

Criteria for exclusion:

i. Surgical history of spine surgery

ii. Patients with an accidental injury to the back

iii. Patients with HIV, HBSAG,etc.

iv. Patients on aspirin or other antiplatelet medications

v. Patients diagnosed with hemolytic disease

vi. Patients diagnosed with severe neuro-vascular disease

vii. Patients diagnosed with anemia

viii. Patients who are not willing to report. 


\section{Raktamokshana}

As described in Samhita, it is an age-old practice to cure a wide range of ailments.

Vitiated blood is expelled out in 2 ways $^{2}$

- Shastrakrut-Prachanna

Karma (superficial pricks), Sira Vedhan (Venesection)

- Ashastrkrut/Anushastra- Jalauka (leech application), shrung (horn application), Alabu (pumpkin application), Ghatiyantra (clay pot application)

To cure the ailment, small superficial pricks are made on the most tender point and an illuminated wick is placed over the skin and the pumpkin is placed over it. The available oxygen was used up by the small flame and eventually vacuum were created thus letting out the vitiated doshas along with the Rakta dhatu.

"तत्र प्रच्छिते तनुबस्तिपटलावनद्धेन

शृड्ग्गेणशोणितमवसेचयेदाचूषणात्, सान्तर्दीपयाऽलाब्वा जलायु का वक्ष्यन्ते $\|<\| "$

Similar mode of treatment is explained in the Chinese medicine and theUnani fraternity, called the 'Hijama'. There are various forms of cupping e.g. dry and wet cupping, lightmedium-strong cupping, moving cupping, needle cupping, hot needle cupping, empty/ flash cupping, full/bleeding cupping, herbal cupping and water cupping.

\section{PROCEDURE OF RAKTAMOKSHANA}

\section{Purva Karma}

- Explaining the whole procedure to the patient and mentally preparing him to undergo the process.

- Informed Written Consent is acquired.

- Materials Required: Variable sizes of cups, Pair of disposable gloves, Cotton/ Gauze, Blade no 11/ 26 no. needle

\section{Pradhana Karma}

- The patient was given a prone position.

- Patients were asked to identify the highest tender point, so the bloodletting site was chosen and sanitized with betadine + spirit.

- A slight incision or a prick was made, and the cup was mounted above it.

- The blood flow was observed for 1015 minutes.

- After sometime the cups were removed and the skin was cleaned without leaving any blood stain behind.

Paschat Karma: medicated oil is applied.

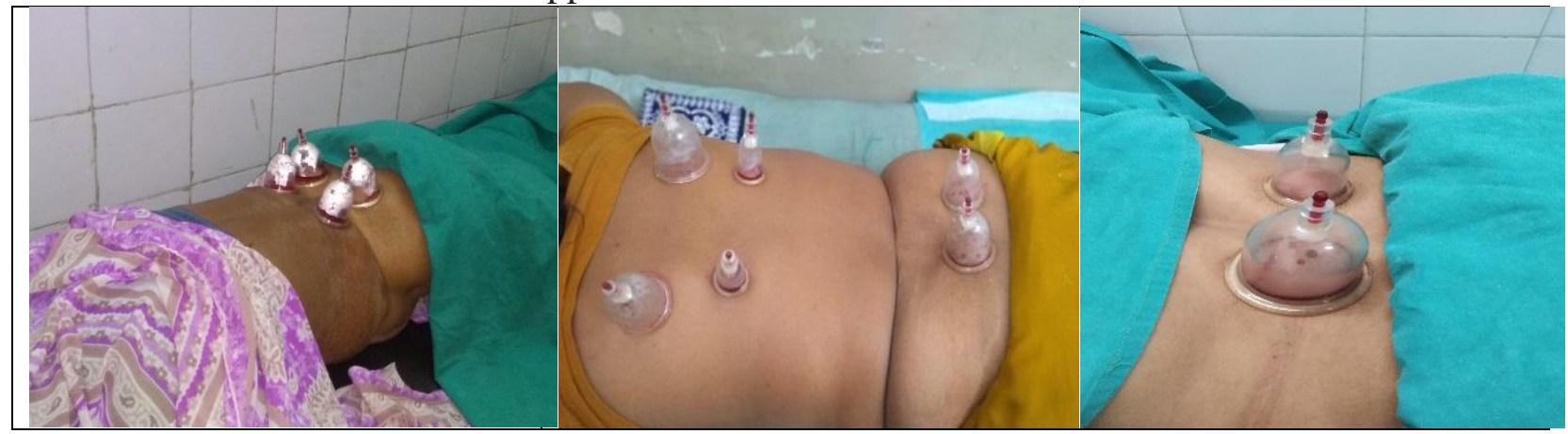




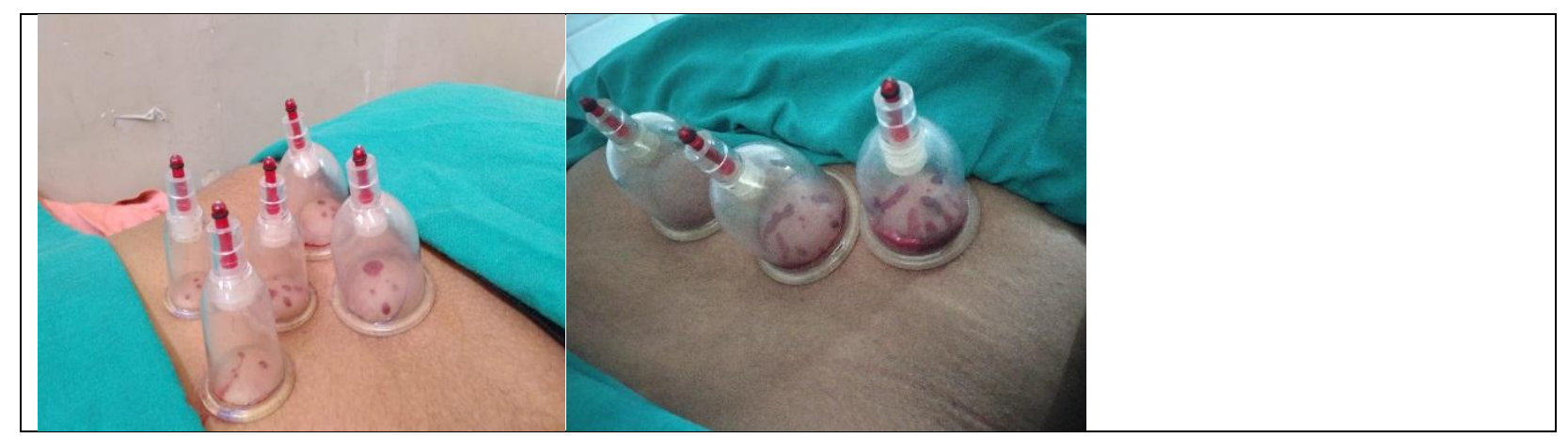

Criteria for evaluation

\begin{tabular}{|c|c|c|c|c|c|}
\hline \multirow[t]{2}{*}{ Parameter } & \multicolumn{5}{|l|}{ Gradation } \\
\hline & 0 & + & ++ & +++ & ++++ \\
\hline Back pain & No pain & $\begin{array}{l}\text { Intermittent } \\
\text { mild pain on } \\
\text { lower back } \\
\text { movement }\end{array}$ & \begin{tabular}{l}
\multicolumn{2}{l}{ Continuous } \\
mild pain \\
radiating \\
hip region
\end{tabular} & $\begin{array}{l}\text { Continuous } \\
\text { severe pain } \\
\text { radiating to hip } \\
\text { region }\end{array}$ & $\begin{array}{l}\text { Severe / non } \\
\text { bearable pain } \\
\text { with } \\
\text { numbness }\end{array}$ \\
\hline $\begin{array}{l}\text { Painful } \\
\text { movement }\end{array}$ & $\begin{array}{l}\text { Complete } \\
\text { movements } \\
\text { without pain }\end{array}$ & $\begin{array}{l}\text { Can do } \\
\text { Complete } \\
\text { movements } \\
\text { with mild pain }\end{array}$ & $\begin{array}{l}\text { Incomplete } \\
\text { movements } \\
\text { with moderate } \\
\text { pain }\end{array}$ & $\begin{array}{l}\text { Incomplete } \\
\text { movements } \\
\text { with severe } \\
\text { pain }\end{array}$ & $\begin{array}{l}\text { Restricted } \\
\text { movements } \\
\text { with severe } \\
\text { pain }\end{array}$ \\
\hline Stiffness & No stiffness & $\begin{array}{l}\text { Mild stiffness } \\
\text { along the } \\
\text { lower back }\end{array}$ & $\begin{array}{l}\text { Moderate } \\
\text { stiffness along } \\
\text { the lower back }\end{array}$ & $\begin{array}{l}\text { Severe } \\
\text { stiffness with } \\
\text { incomplete } \\
\text { lumbar } \\
\text { movements }\end{array}$ & $\begin{array}{l}\text { Severe } \\
\text { stiffness with } \\
\text { restricted } \\
\text { movements }\end{array}$ \\
\hline $\begin{array}{l}\text { Tingling } \\
\text { numbness }\end{array}$ & $\begin{array}{l}\text { No } \\
\text { numbness }\end{array}$ & $\begin{array}{l}\text { Mild tingling } \\
\text { sensation } \\
\text { without } \\
\text { numbness }\end{array}$ & $\begin{array}{l}\text { Mild tingling } \\
\text { sensation with } \\
\text { intermittent } \\
\text { numbness }\end{array}$ & $\begin{array}{l}\text { Moderate } \\
\text { tingling } \\
\text { sensation with } \\
\text { continuous } \\
\text { numbness }\end{array}$ & $\begin{array}{l}\text { Severe } \\
\text { tingling } \\
\text { numbness } \\
\text { over entire } \\
\text { lower limb }\end{array}$ \\
\hline
\end{tabular}

\section{OBSERVATIONS:}

Raktamokshana was done using the Cupping

Subjective symptoms presented to patients were examined before and after

\begin{tabular}{|l|c|c|c|c|}
\hline Patient No. & Backpain & Painful Movement & Stiffness & Tingling Numbness \\
\hline $\mathbf{1}$ & 3+ to $1+$ & 2+ to 0 & 2+ to $1+$ & 1+ to 0 \\
\hline $\mathbf{2}$ & 3+ to $1+$ & 3+ to $1+$ & 1+ to + & 2+ to $1+$ \\
\hline $\mathbf{3}$ & 1+ to 0 & 2+ to 0 & 0 & 1+ to 0 \\
\hline $\mathbf{4}$ & 3+ to $1+$ & 3+ to $1+$ & 0 & $2+$ to $1+$ \\
\hline $\mathbf{5}$ & 3+ to $1+$ & 2+ to $1+$ & 2+ to $1+$ & 2+ to $1+$ \\
\hline $\mathbf{6}$ & 2+ to 0 & 2+ to 0 & 0 & 1+ to 0 \\
\hline
\end{tabular}




\begin{tabular}{|l|c|c|c|c|}
\hline $\mathbf{7}$ & $3+$ to $1+$ & $3+$ to $1+$ & $1+$ to 0 & $2+$ to $1+$ \\
\hline $\mathbf{8}$ & $1+$ to 0 & $2+$ to $1+$ & $1+$ to 0 & $2+$ to $1+$ \\
\hline $\mathbf{9}$ & $3+$ to $1+$ & $3+$ to $1+$ & $1+$ to 0 & $2+$ to $1+$ \\
\hline $\mathbf{1 0}$ & $3+$ to 0 & $2+$ to 0 & $2+$ to $1+$ & $1+$ to 0 \\
\hline
\end{tabular}

Based on clinical study, the observations were noted using the criteria of assessment and result were recorded as per case record form and conclusion was drawn on the basis of the observed results.

OVERALL PERCENTAGE RELIEF ON ALL SYMPTOMS

\begin{tabular}{|l|l|c|c|c|c|}
\hline \multirow{2}{*}{ Sr. No. } & \multirow{2}{*}{ Features } & \multicolumn{2}{|c|}{ Mean Score } & \multirow{2}{*}{$\begin{array}{c}\text { Mean } \\
\text { Difference }\end{array}$} & Percentage relief \\
\cline { 3 - 4 } & & BT Score & AT Score & 1.9 & $76 \%$ \\
\hline $\mathbf{2}$ & Backpain & 2.5 & 0.6 & 1.8 & $75 \%$ \\
\hline $\mathbf{3}$ & Painful Movement & 2.4 & 0.6 & 0.7 & $70 \%$ \\
\hline $\mathbf{4}$ & Stiffness & 1.0 & 0.3 & 1 & $62.5 \%$ \\
\hline
\end{tabular}

Marked reduction in severity of complains was seen in the patients after the use of cupping method for Raktamokshana, which was significant. $76 \%$ relief was seen in backpain, $75 \%$ relief was seen in painful movements, $70 \%$ relief was seen in Stiffness and $62.5 \%$ relief was seen in Tingling numbness.

\section{DISCUSSIONS}

Cupping therapy is a primordial mode of treatment that has been in use in the management of a broad range of conditions. There are many forms of cupping therapy; however, dry and wet cupping are the two main types. Dry cupping drags the skin into the cup without scarifications, while in wet cupping the skin is lacerated so that blood is drawn into the cup.

Acharya Charaka has described Basti Karma, Raktamokshana and Agni Karma in the management of Katigata-Vata. Raktamokshana is also accepted as half of the therapeutic measure in Shalyatantra like Basti in Kayachikitsa. In PanchaKarma Chikitsa, the vitiated doshas are purified whereas in Raktamokshana vitiated Rakta Dhatu is removed. The susceptibility of Rakta towards impurity is so versatile that the Acharya Sushruta declared 'Rakta' as fourth Dosha $a^{3}$. Acharya Sushruta has mentioned that if the vitiated vata dosha has localized to a particular site then Raktamokshana can be carried out with the help of shrunga avcharana ${ }^{4}$.

By Raktamokshana we let out vitiated Rakta Dhatu along with vitiated Doshas thereby relieving symptoms of Katigata-Vata. Similarly, in the present study vitiated Doshas along with Rakta Dhatu were let out by pricking with needle on affected area, the vacuum created by the Cupping method helps the vitiated blood to ooze out which gives spontaneous relief from symptoms of Katigata-Vata due to release of Doshas with the blood from the body.

Probable mode of action of cupping therapy:

- Concurring to a Chinese research article, cupping therapy operates through creating specific variations in local tissue structures,consequently to local negative pressure in the cups used which stretches the nerve and muscle triggering an increase in blood circulation. This practice of healing cup therapy is non-invasive in nature and functions on the Chinese 
hypothesis that ailments are caused when the "qi" or "chi" or the life force of the body is interrupted because of some ailment. Cupping therapy works to reinstate this equilibrium and provide pain management.

- Another theory suggests that, Spasm is the increased muscle tone in a localized part. In the presence of spasm there is capillary constriction which lessens the blood flow that curbs the flow of nutrients and oxygen to the area and retention of waste products that produces more spasm. This spasm can be broken by gliding cupping/Massage cupping stimulates the sensory nerve endings and production of mild pain; massage blocks the pathways of this pain. The mechanical movement stretches the individual fibers of soft tissue and reduces their tension. Helps in the removal of metabolic waste products as these substances are noxious to the tissue and irritate the free nerve endings, this result in reduction of pain. All these factors together aid to reduce the spasm.

- Gate Control Theory: Gliding cupping may interfere with pain signals pathway to brain, a process called the "gate control theory", according to experts, Pain impulses run toward the spinal cord and then up the cord and into the brain. It's only when they reach the brain that these impulses, are perceived as pain. When rub with gliding cupping, it sends other impulses along the same nerves. When all these impulses try to reach the brain through nerves, the nerves get clogged with signals. The results: Most of them won't reach the brain and if the pain signals do not reach the brain, won't feel pain.
Thus, gliding cupping works by 'closing the gate' that pain impulses have to pass through.

- Increasing blood circulation theory: By increasing the blood circulation, by removing the inflammatory products and toxins out by cupping therapy which will reduce inflammation and pain

- One of the controversial views concerning cupping therapy is that it has only a placebo effect. This placebo theory about cupping therapy will remain alive until a reliable and valid mechanism is found out.

\section{CONCLUSION:}

After using Cupping method as a treatment modality in patients with Katigata-Vata, it can be concluded that the use of Cupping methodimparts measurable reduction in the intensity of the major symptoms of Katigata-Vata.Cupping method is the - simple and effective treatment in adjunct to other treatment modalities for Back pain

\section{REFERENCES}

1. Dr Brahmanand Tripathi, Siravyadhvidhiadhayay, Ashtang Hridayam, Chaukhambha Sanskrit Pratishthan, Delhi, edition reprinted 2014, page no 294-303

2. Kaviraj ambikadutta shastri, chaukhambhasanskritasamsthan, edition 2nd, Varanasi 2008 ,Susruta Samhita, Sutra Sthana, JalaukavacharniyaAdhyaya, $13^{\text {th }}$

3. Kaviraj ambikadutta shastri, chaukhambhasanskritasamsthan, edition 2nd, Varanasi 2008 ,Susruta Samhita, Sutra Sthana, Shonitavarnaniyaadhyaya, $14^{\text {th }}$

4. Kaviraj ambikaduttashastri,Susruta Samhita, 1st edition, Chikitsasthana, Katigata-Vatachikitsadhyay, $4^{\text {th }}$ 
5. Kaviraj ambikadutta shastri, Susruta Samhita, 1st edition, Chikitsasthana, Maha-Katigata-Vatachikitsadhyay, 5 th

6. Vagbhata. AstangaSangraha. Text with English Translation, 1 st Ed. Varanasi: ChaukambhaVisvabharati, 2006; page no. 474-479.

7. Shastri RD, editor. Charak Samhita of Agnivesha, Reprint ed., SutraSthana, Vidhishonitiyadhyay, $24^{\text {th }}$

8. Shastri RD, editor. Charak Samhita of Agnivesha, Reprint ed., Chikitsa Sthana, Katigata-Vatachikitsadhyaya, $28^{\text {th }}$

9. Singh MS, Kotangale YT, Burley AK. A comparative clinical study on the effect of Matra Basti and Rasna Gugglu in the management of Katigata-Vata. Ayurlog Natl J Res Ayu Sci. 2013;1:16-20

10. Bakhashi B, Gupta SK, Rajagopala M, Bhuyan C. A comparative study of Agni

Karma with Lauha, Tamra and Panc hadhatuc Shalakas in Katigata-Vata (Sciatica) Ayu. 2010;31:240-4

11. Pandey RK, Bhatted S. Effect of ErandaMooladi Basti along with other Ayurvedic formulation in Katigata-Vata (sciatica): A case report. Ann Ayurvedic Med. 2013;2:109-13.
12. Lohith BA, Girish KJ. Clinical study to assess the effect of yoga in Katigata-Vata. IJRAP. 2013;4:50-3.

13. Chaturvedi S, Katara P. Role of AgniKarma and Rakta Mokshana Karma in Gidhrasi WSR to Sciatica. International Journal Science and Research. 2014;3:35962.

14. Umale NP, Shylaja RK. Efficacy of Siravedha in the management of pain in Katigata-Vata. International Ayurvedic

Medical Journal. 2013;1:50-5

15. The medical perspective of cupping therapy: Effects and mechanisms of action Abdullah M.N. Al-Bedah a, Ibrahim S. Elsubai a, *, Naseem Akhtar Qureshi a , Tamer Shaban Aboushanab a , Gazzaffi I.M. Ali a , Ahmed Tawfik El-Olemy a, b , Asim A.H. Khalil a , Mohamed K.M. Khalil a , Meshari Saleh Alqaed a a National Center of Complementary and Alternative Medicine, Ministry of Health, Riyadh 11662, Saudi Arabia b Public Health and Community Medicine Department, Faculty of Medicine, Tanta University, Egypt

16. Standardization of Cupping Therapy Points And Mechanism Of Action In The Light Of Science Dr. Izharul Hasan Unani Consultant, Ayush Wellness Clinic, President's Estate, New Delhi, India.

Conflict of Interest: Non

Source of funding: Nil

Cite this article:

Evaluation of the efficacy of Raktamokshana by cupping method in Vatapradhana Katigata-Vata.

Shivanand F. Kawane, Yogesh Sharma, Shital S. Kawane

Ayurlog: National Journal of Research in Ayurved Science- 2021; (09) (02):01- 07 